\title{
FILOSOFI WANITA: SEBUAH INSPIRASI DARI SURAT AN NISA
}

\author{
Isti'anah Abubakar \\ istianah.2f@pai.uin-malang.ac.id \\ UIN Maulana Malik Ibrahim Malang
}

\begin{abstract}
The topic of women is always interesting to be discussed to provide interesting directions or themes, so the Qur'an has given concrete instructions. More than 5 letters that make women the theme of the book, namely QS Nisa decree letter, Mary nineteenth letter, Al Mujadilah letter number twenty, QS Al Mumtahanah sixtieth letter and At Thalaq sixty-fifth letter. By making QS An Nisa as a foothold of the study, it is expected to be able to provide improvement, guiding lines against the steps of today's women to be able to always be in the corridors of Divine Rabb. Women as special figures do not have to position themselves as someone who must be approved but also someone who is able to argue. An Anisa can be made to do both of these things. This balanced relationship can only be done as long as the assessment of eternal teaching is carried out by istiqamah. This behavior will produce rice fields and gold producers that are needed by the state and nation.
\end{abstract}

Keywords: Philosophy, QS An Nisa', Women

\section{Abstrak}

Tema wanita selalu menarik untuk diperbincangkan untuk memberikan arah perbincangan atau tema yang bermakna, maka Al Qur'an telah memberikan pedoman kongkritnya. Setidaknya ada 5 surat yang menjadikan wanita sebagai tema pokonya, yaitu QS An Nisa surat keempat, Maryam surat ke sembilan belas, Al Mujadilah surat kelima puluh delapan, QS Al Mumtahanah surat keenam puluh dan At Thalaq surat keenam puluh lima. Dengan menjadikan QS An Nisa sebagai pijakan kajian, diharapkan mampu memberikan penguatan, guide line terhadap gerak langkah wanita masa kini untuk dapat selalu dalam koridor Illahi $R a b b$. Wanita sebagai makhluk istimewa tidak harus memposisikan diri sebagai sosok yang harus dipahami tapi juga sosok yang mampu memahami. Surat An Nisa dapat dijadikan pijakn untuk melakukan kedua hal tersebut. Relasi yang seimbang ini hanya akan bisa dilakukan selama pengkajian terhadap ajaran abadi selalu dilakukan secara istiqamah. Perilaku inilah yang akan menghasilkan sawah dan produsen generasi emas yang sangat dibutuhkan negara dan bangsa.

Kata Kunci: Filosofi, Surat An Nisa', Wanita

\section{PENDAHULUAN}

Tema wanita selalu menarik untuk diperbincangkan untuk memberikan arah perbincangan atau tema yang bermakna, maka Al Qur'an telah memberikan pedoman kongkritnya. Setidaknya ada 5 surat yang menjadikan wanita sebagai tema pokonya, yaitu QS An Nisa surat keempat, Maryam surat ke sembilan belas, Al Mujadilah surat kelima puluh delapan, QS Al Mumtahanah 
surat keenam puluh dan At Thalaq surat keenam puluh lima. Kelimanya memberikan panduan kongkrit akan apa yang dihadapi dan harus dilakukan wanita. Surat An Nisa dengan 176 ayat menjelaskan posisi wanita di semua aspeknya, baik sebagai pribadi, keluarga dan masyarakat serta dengan hubungannya dengan Rabbnya. Adapun Surat Maryam memberikan pedoman terkait perilaku idealnya wanita yang terinspirasi dari wanita sebelum datangnya Islam. Adapun ketiga surat lainnya lebih menekankan pada posisi wanita dalam keluarga. Hal ini mengindikasikan bahwa Al Qur an memberikan pedoman ideal dalam membangun relasi dengan wanita di semua aspeknya yang lebnih dikongkritkan dengan relasi Nabi Muhammad dengan para istri, anak yang jauh berbeda dengan kebiasaan jahiliyah. Seperti diketahui, salah satu perbincangan jahiliyah adalah perilakunya atau bermuamalahnya terutama terhadap wanita (Istianah, 2012). Hal ini diperkuat oleh Syafiq seorang aktivis perempuan, bahwa ada 7 ciri dasar perlakuan kaum perempuan masa jahiliyah yang ditolak Islam ( Syafiq Hasyim, 2001: 29-30):

1. Perempuan adalah manusia yang tidak dikenal oleh undang- undang

2. Perempuan dipersepsikan sebagai harta benda

3. Perempuan tidak memiliki hak talak

4. Perempuan tidak memiliki hak waris

5. Perempuan tidak memiliki hak memelihara anaknya

6. Perempuan tidak memiliki kebebasan membelanjakan hartanya

7. Penguburan bayi perempuan hidup-hidup

Adanya revolusi paradigma sebelum dan sesudah Islam tentang wanita, masih menjadikannya trending topic. Di satu sisi, posisi dan peran wanita bisa dipahami dan dijalankan sesuai dengan fitrahnya tapi di sisi lain masih ada beberapa yang menimbulkan permasalahan yang didasari pemahaman mendeskriditkan atau memarginalkan posisi perempuan. Kondisi inilah yang kemudian melahirkan gerakan feminis dengan mengusung kesetaraan gender, serta perkembangan dan pergeseran posisi dan peran wanita yang diakibatkan perubahan masa. Masih adanya stigma normatif dan budaya yang memarginalkan perempuan menstimulasi gerakan-gerakan perempuan. Padahal bila ditelaah lebih lanjut, maka ikhtilaf itu disebabkan adanya kedangkalan terkait pengetahuan (Quraisy Shihab, 2001).

Namun karena masih adanya pandangan yang memposisikan wanita sebagai makhluk lemah, makhluk yang hanya mengandalkan seksualitas dan sensualitas, sosok yang diposisikan pada $3 \mathrm{M}$ nya filosofi Jawa merupakan indikasi kongkrit masih perlunya upaya eksplorasi secara mendalam tentang wanita, salah satunya melalui surat An Nisa, sebagai salah satu dalam Al Qur an yang paling banyak atau detail membahas tentang wanita dibanding surat yang lain. Rasyid Ridha dalam Syafiq (2001) mengatakan bahwa dinamakan surat An Nisa dikarenakan pada awal pembukaannya menuturkan tentang perempuan dan hukum- hukum yang berkenaan dengannya. 
Syafiq menguatkan bahwa substansi Surat An Nisa adalah memuat pelbagai persoalan yang berkaitan dengan relasi antara laki-laki dan perempuan baik sebagai manusia, sebagai suami istri atau dalam aspek kehidupan lainnya. Dengan menjadikan QS An Nisa sebagai pijakan kajian, diharapkan mampu memberikan penguatan, guide line terhadap gerak langkah wanita masa kini untuk dapat selalu dalam koridor Illahi Rabb.

\section{PEMBAHASAN}

\section{Mengenal Lebih Dekat Surat An Nisa : Urgensi Kajiannya}

Surat An Nisa merupakan surat Madaniyah yang terpanjang sesudah surat Al Baqarah dan disebut dengan Surat An Nisa Kubra dikarenakan cakupan tema tentang wanita sangat komprehensif dibanding pada 4 surat lainnya terutama surat At Thalaq yang disebut surat An Nisa Sughra. Ada 176 ayat dalam surat An Nisa yang memperbincangakan banyak hal, salah satunya tentu saja wanita. Al Maraghi (4:312) menjelaskan bahwa topik-topik dalam Surat An Nisa ini adalah :

a. perintah agar bertakwa kepada Allah secara sembunyi- sembunyi atau terangterangan

b. mengingatkan orang yang diajak bicara, bahwa mereka berasal dari satu jiwa

c. hukum-hukum pertalian kerabat dan bersimenda

d. hukum-hukum yang menyangkut masalah pernikahan dan pembagian waris

e. hukum-hukum mengenai peperangan

f. perdebatan dengan orang-orang Ahli Kitab

g. sebagian berita yang menelanjangi perilaku orang-orang munafik

h. pembicaraan dengan kaum Ahli Kitab sampai batas 3 ayat sebelum akhir surah

Kedelapan topik yang disampaikan Maraghi di atas, maka topik yang terkait erat dengan wanita tertera pada poin c dan d. Kedua poin tersebut sangat berhubungan erat dengan fitrah wanita, makhluk yang disiapkan Tuhan untuk mencetak generasi melalui rahimnya, sebuah amanah yang sangat istimewa. Seperti yang disampaikan Rasyid Ridha di atas bahwa QS An Nisa ini memperbincangkan relasi kepada wanita yang ideal, sebagai dzikra untuk masyarakat pada waktu itu, masyarakat yang relasinya dengan wanita sangat merugikan. Maka ini juga merupakan salah satu bagian penting terkait misi Muhammad SAW, sebagai penyempurna akhlak, dalam hal ini menyempurnakan akhlak wanita dan bagaimana membangun relasi dengan wanita. Dengan kata lain QS An Nisa' diyakini mampu meluruskan persoalan-persoalan kontroversial yang dialamatkan untuk perempuan, salah satunya dengan penciptaannya.

Terkait hal ini, maka QS An Nisa diawali dengan ayat yang menekankan 3 hal: 
a. Perintah bertakwa

b. Penjelasan tentang penciptaan manusia

c. Saling membina hubungan silaturahmi

Ketiga hal di atas, merupakan dasar dalam membangun relasi dengan siapapun, terutama dengan wanita. Untuk memperjelas kandungan Qs An Nisa dapat dipaparkan sebagai berikut :

Tabel 1. Kandungan Qs An Nisa

\begin{tabular}{|c|c|c|}
\hline No & Ayat & Ketrangan \\
\hline 1 & $\begin{array}{l}\text { 1-6, } \\
\text { dengan } \\
\text { keluarga }\end{array}$ & $\begin{array}{l}\text { a. Perintah bertaqwa } \\
\text { b. Pelurusan terkait penciptaan manusia } \\
\text { (baca wanita) } \\
\text { c. Jaga silaturahmi } \\
\text { d. Sikap terhadap anak yatim } \\
\text { e. Aturan nikah - poligami } \\
\text { f. Pemberian mas kawin ( harus penuh kerelaan) } \\
\text { g. Aturan tentang harta anak yatim }\end{array}$ \\
\hline 2 & $\begin{array}{l}\text { 7-14, } \\
\text { waris }\end{array}$ & $\begin{array}{l}\text { h. Hukum waris dimana } 2 \text { ayat terakhir menjadi } \\
\text { pengingat untuk tidak melanggar ketentuan Allah }\end{array}$ \\
\hline 3. & $15-18$ & $\begin{array}{l}\text { i. Aturan bagi perbutan keji yang melakukan } \\
\text { j. } \quad \text { Perintah untuk segera bertaubat }\end{array}$ \\
\hline 4. & $19-21$ & k. hubungan suami istri \\
\hline 5. & $22-28$ & $\begin{array}{l}\text { l. hukum perkawinan, siapa yang boleh untuk } \\
\text { dinikahi }\end{array}$ \\
\hline 6. & $29-33$ & m. melindungi harta milik \\
\hline 7. & $34-35$ & n. relasi suami-istri \\
\hline 8 & $36-42$ & $\begin{array}{l}\text { o. membangun relasi baik dengan orang tua dan } \\
\text { karib kerabat } \\
\text { p. siksaan bagi orang yang kikir } \\
\text { q. tidak menafkahkan harta dengan } \\
\text { riya' } \\
\text { r. anjuran untuk bersedekah } \\
\text { s. peringatan bagi orang kafir }\end{array}$ \\
\hline 9. & $43-57$ & $\begin{array}{l}\text { t. menjaga shalat } \\
\text { u. deskripsi orang-orang yang mengingkari } \\
\text { ayat-ayat Allah }\end{array}$ \\
\hline 10. & $\begin{array}{l}\text { 58-70, } \\
\text { dasar- dasar } \\
\text { pemerintahan }\end{array}$ & $\begin{array}{l}\text { v. adil dan amanah } \\
\text { w. mentaati Rasul dan ulul Amri }\end{array}$ \\
\hline 11. & $\begin{array}{l}71-96, \\
\text { perang } \\
\text { dan adab- } \\
\text { adabnya }\end{array}$ & x. jihad, meluruskan niat semuanya karena Allah \\
\hline 12. & $97-104$ & $\begin{array}{ll}\text { y. } & \text { keutamaan hijrah } \\
\text { z. } & \text { konsekwensi hijrah }\end{array}$ \\
\hline 13. & $105-122$ & Adil dan berani menegakkan kebenaran \\
\hline 14. & $123-126$ & Persaman balasan untuk laki-laki dan perempuan \\
\hline
\end{tabular}




\begin{tabular}{|c|l|l|}
\hline 15. & $127-130$ & $\begin{array}{l}\text { Hukum berumahtangga, ditkankan pada } \\
:\end{array}$ \\
\hline 16. & $131-134$ & $\begin{array}{l}\text { relasi terhadap wanita nusyuz } \\
-\quad \text { menggauli wanita } \\
-\quad \text { konsekwensi dalam berpoligami }\end{array}$ \\
\hline 17. & $135-136$ & $\begin{array}{l}\text { Menjadikan Allah sebagai sandaran solusi atas segala } \\
\text { permasalahan yang muncul }\end{array}$ \\
\hline 18. & $137-147$ & $\begin{array}{l}\text { Derlaku adil jika menjadi saksi bagi siapapun } \\
\text { tentangnya }\end{array}$ \\
\hline 19. & $148-149$ & $\begin{array}{l}\text { Membangun relasi dengan membangun komunikasi } \\
\text { dengan perkataan yang baik }\end{array}$ \\
\hline 20. & $150-162$ & $\begin{array}{l}\text { Siksaan bagi orang munafik dan balasan bagi orang } \\
\text { yahudi }\end{array}$ \\
\hline 21. & $163-175$ & $\begin{array}{l}\text { Penguatan bahwa ajaran yang dibawa nabi-nabi Allah } \\
\text { adalah sama dan saling meyempurnakan }\end{array}$ \\
\hline
\end{tabular}

Berdasarkan pemetaan yang telah penulis lakukan, maka terlihat jelas bahwa wanita menjadi topik yang sangat detail. Hal ini mengindikasikan bahwa Islam memposisikan wanita sebagai makhluk Tuhan yang paling istimewa, bukan hanya sexy. Kedetailan ini tentu saja mempermudah siapapun untuk membangun relasi dengan wanita, sebagai sosok yang diagungkan dan dimuliakan oleh Islam. Poin 4, 7 dan 15 setidaknya bisa dijadikan solusi ideal bagi hal tersebut di atas, dikarenakan sinergi dan harmonisasi sebuah relasi sangat dikedepankan oleh Islam dengan konsep ikha'nya.

Al Ghazali dalam Abubakar ( 1994: 134) sendiri mengingatkan bahwa ada 10 karakter wanita tidak baik, yang kesemuanya telah diberikan solusinya pada surat An Nisa. Adapun 10 karakter wanita tersebut adalah :

1. Wanita ana-nah, wanita yang setiap saat suka mengeluh

2. Wanita mana-nah, wanita yang suka menyebut-nyebut kebaikannya kepada suami atau kepada orang yang pernah menerima kebaikannya

3. Wanita hana-nah, wanita yang suka menyatakan kasih sayangnya kepada mantan kekasihnya dulu

4. Wanita hada-qah, wanita yang suka melemparkan pandangan matanya kepada sesuatu lalu menyatakan keinginannya dan memaksaka suami untuk membelikannya

5. Wanita bara-qah, wanita yang setiap hari berdandan dan bersolek saja tanpa mau bekerja untuk melayani suaminya

6. Wanita yang syadaqah, wanita yang suka asal ngomong, asal menuduh tanpa menanyakan dahulu persoalan yang sebenarnya

7. Wanita yang mukhtali'ah, wanita yang suka minta cerai

8. Wanita yang mubariyah, wanita yang suka membanggakan diri tentang kebaikan 
dirinya tentang kecantikan rupa

9. Wanita ahirah, suka berbuat serong dengan laki-laki lain

10. Wanita yang nasyiz, wanita yang suka membangkang terhadap suaminya

\section{Wanita : Penciptaan dan Filosofinya}

Posisi wanita yang telah dijelaskan secara detail dalam surat An Nahl, masih saja menimbulkan ikhtilaf dikarenakan pemahaman normatif yang tekstualis. Posisi wanita sebelum Islam sangat jauh dari kemuliaan, terlihat dari ayat berikut ini:

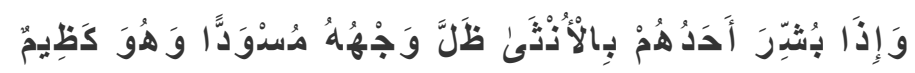

58: "Dan apabila seseorang dari mereka diberi kabar dengan (kelahiran) anak perempuan, hitamlah (merah padamlah) mukanya, dan dia sangat marah"

Berdasarkan ayat tersebut di atas, maka sangat wajar bila terdapat budaya sebagian masyarakat jahiliah yang mampu mengubur anak perempuannya hidup-hidup seperti dijelaskan dalam ayat $\mathrm{Al}$ Qur an berikut ini:

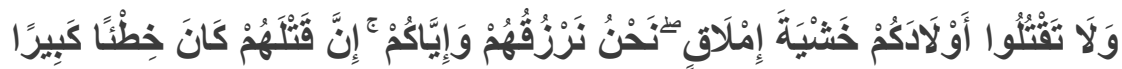

31. "Dan janganlah kamu membunuh anak-anakmu karena takut kemiskinan. Kamilah yang akan memberi rezeki kepada mereka dan juga kepadamu. Sesungguhnya membunuh mereka adalah suatu dosa yang besar. (QS Al isra: 31)"

Berdasarkan kedua ayat di atas, maka bisa dipahami lebih mendalam bagaimana posisi wanita sebelum Islam datang. Hal inilah yang hendak diluruskan Islam, diingatkan kembali bahwa laki-laki dan perempuan adalah sama, yang membedakan hanyalah ketaqwaannya. Seperti pada ayat berikut ini:

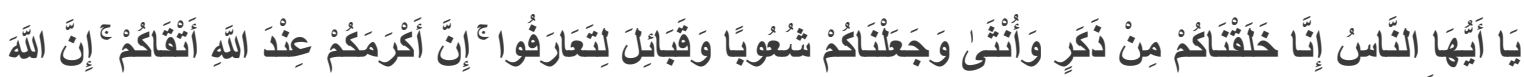 عَلِيمٌ خَبِيرٌ}

13. Hai manusia, sesungguhnya Kami menciptakan kamu dari seorang laki-laki dan seorang perempuan dan menjadikan kamu berbangsa- bangsa dan bersuku-suku supaya kamu saling kenal-mengenal. Sesungguhnya orang yang paling mulia diantara kamu disisi Allah ialah orang yang paling takwa diantara kamu. Sesungguhnya Allah Maha Mengetahui lagi Maha Mengenal. (QS. Al Hujurat: 13)

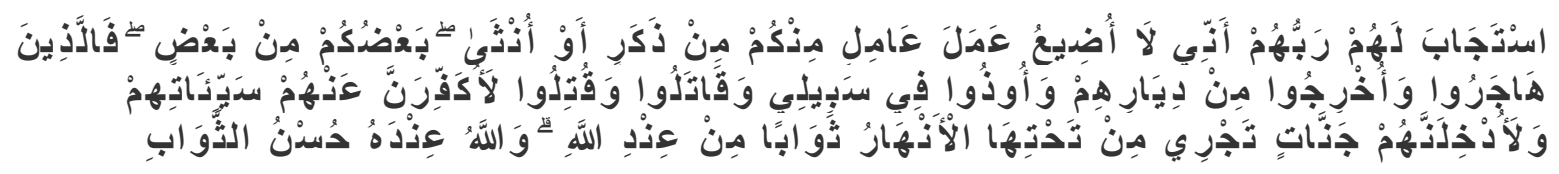

195: Maka Tuhan mereka memperkenankan permohonannya (dengan berfirman): "Sesungguhnya Aku tidak menyia-nyiakan amal orang-orang yang beramal di antara kamu, 
baik laki-laki atau perempuan, (karena) sebagian kamu adalah turunan dari sebagian yang lain. Maka orang-orang yang berhijrah, yang diusir dari kampung halamannya, yang disakiti pada jalan-Ku, yang berperang dan yang dibunuh, pastilah akan Ku-hapuskan kesalahankesalahan mereka dan pastilah Aku masukkan mereka ke dalam surga yang mengalir sungai-sungai di bawahnya, sebagai pahala di sisi Allah. Dan Allah pada sisi-Nya pahala yang baik". (QS. Al Imran: 195)

Keistimewaan dan ta'kid di atas agak dikaburkan dengan adanya beberapa ayat dan hadits yang " dipahami" sangat merugikan wanita, tidak adil. Penciptaan wanita serta porsi warisan wanita merupakan di antara topik yang masih selalu diperdebatkan. Adanya hadits berikut ini, misalnyaj

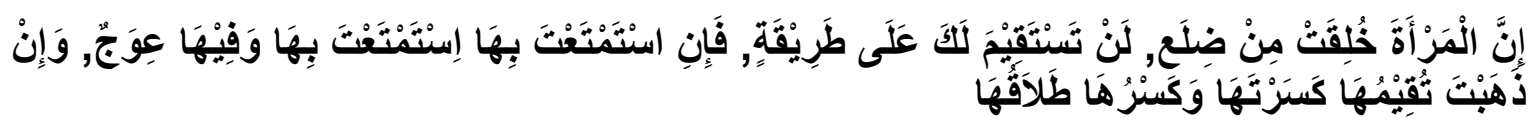

Artinya: Sesungguhnya wanita diciptakan dari tulang rusuk, ia tidak bisa lurus untukmu di atas satu jalan. Bila engkau ingin bernikmat-nikmat dengannya maka engkau bisa bernikmat-nikmat dengannya namun padanya ada kebengkokan. Jika engkau memaksa untuk meluruskannya, engkau akan memecahkannya. Dan pecahnya adalah talaknya." (HR. Muslim).

Jika dimaknai secara tekstual, terlihat adanya deskripsi yang agak janggal dengan menyamakan wanita dengan tulang rusuk yang bengkok. Hal ini jika dipahami secara lahir memang akan sangat membuka celah bahan diskusi yang kadangkala melanggar koridor agam. Maka disinilah dibutuhkan penelaahan bijaksana berdasarkan ilmu-ilmu terkait. Padahal pada hadits tersebut terdapat makna kiasan yang sebenarnya adalah bahwa agar laki-laki menghadapi perempuan dengan bijaksana karena ada sifat, karakter dan kecenderungan yang tidak sama. Hal ini diperkuat dengan pernyataan Ali dalam Nahjul Balaghah (Abul Hasan, 2000, p. 174) bahwa ada 3 karakteristik wanita:

1. Lemah dalam iman, karena da halangan

2. Lemah dalam persaksian karena akan didenganrkan dengan 2 orang saksi lemah dalam warisan, warisan setengah dari warisan laki-laki

Padahal hadits lain menyatakan sebagai berikut:

Barangsiapa yang mendapat cobaan dari anak-anak perempuannya tetapi dia berbuat baik terhadap mereka niscaya mereka akan menjadi penghalang baginya dari azab neraka (Shahih Bukhori: 1418, 5995).

Berdasarkan poin ini bisa ditegaskan bahwasannya ikhtilaf didasarkan pada sesuatu yang parsial, memahami satu hadits tanpa melihat hadits lain dan kita membuang energi untuk sesuatu yang posisinya jauh di bawah Al Qur an, sementara Al Qur an sendiri telah memberikan penjelasan kongkrit mengenai penciptaan manusia itu sendiri, baik laki-laki dan perempuan. Maka bisa dikatakan lebih lanjut, bahwa mengembalikan semuanya pada Allah, menyakini apa 
yang digariskan Allah adalah terbaik dan pasti ada hikmahnya menjadi terapi pikiran yang bisa diikhtiarkan.

\section{Adabul Mar'ah : Belajar dari Ummahatul Mukminin}

Kita tidak bisa memilih untuk menjadi laki-laki atau perempuan, karena sebagai makhluk maka kita hanya mengikuti skenario yang telah digariskan oleh Allah seperti dalam firmanNya:

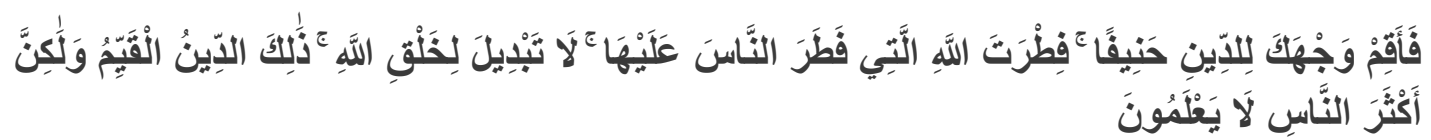

30. Maka hadapkanlah wajahmu dengan lurus kepada agama Allah; (tetaplah atas) fitrah Allah yang telah menciptakan manusia menurut fitrah itu. Tidak ada peubahan pada fitrah Allah. (Itulah) agama yang lurus; tetapi kebanyakan manusia tidak mengetahui. (QS. Ar ruum: 30 )

Berdasarkan ayat di atas, maka jika kita sudah “ perempuan” maka tinggal membangun relasi, baik terhadap Rabb, diri sendiri, orang tua, suami, anak maupun masyarakat yang kesemuanya telah dideskripsikan dalam Al Qur an, terutama dalam surat An Nisa. Hal ini masih diperkuat dengan menjadikan Nabi Muhammad dan para istrinya merupakan tauladan kongkrit bagaiman membangun relasi sesuai yang telah digariskan.

Penelitian ilmiah menguatkan bahwa memang ada perbedaan karakteristik antara lakilaki dan perempuan yang keduanya diciptakan untuk saling melengkapi. Ditemukan bahwa otak wanita pada wilayah bahasa dan aktivitas motorik serta emosi tumbuh enam kali lebih cepat daripada laki-laki. Sementara otak pria pada wilayah deskripsi kosong, lapang dan pembatasan tujuan tumbuh lebih cepat enam kali lipat dibanding otak wanita. (Syarief Hade (ed), 2010, p. 150) Sementara penelitian lain menyatakan bahwa kaum wanita berkarakter tidak nyaman dalam menanggapi pendapat dari sesama wanita. (Syarief Hade (ed), 2010, p. 160) Julia Hery dari Universitas New South wales Sidney Australia menyatakan bahwa kehamilan menyebabkan memori wanita berkurang. Ketiga kecenderungan di atas menjadi wahana untuk memilah dan menentukan pola relasi apa yang akan dilakukan. berdasarkan kajian di atas, maka ada 2 aspek utama yang bisa dijadikan adabul mar'ah yaitu al haya (merasa malu) dan iffah (menjaga diri). Kedua hal inilah yang harus diketahui untuk kemudian dipahami dan diinternalisasikan sebagai adabul mar'ah sejati sehingga ciri-ciri wanita yang disebutkan Al Ghazali di atas dapat dihindari.

Adapun top figure yang memang telah teruji, dalam hal ini Ummahat Al mukminin, merupakan keniscayaan untuk dijadikan modelling dalam memetakan kembali adab mar'ah yang seyogyanya dimiliki oleh wanita. Metafora profil umahatul mukminin (Syafii Antonio, 2010): (1) penenang -Khadijah, (2) pengasuh - Saudah, (3) cerdas-Aisyah, (4) Hafsaf - penjaga amanah, (5) dermawan - Zainab binti Khuzaimah, (6)Ummu Salamah-penasehat, (7)ahli sedekah - Zainab binti Jahsyi, (8) menjaga harga diri - Juwairiyah, (9) Diplomat - Shafiyah, (10) Pemersatu/pendamai Ummu Habibah binti Abu Sufyan, (11) Penjaga Silaturahmi - Maimunah, 
(12) Berpandangan Luas/Bijak - Mariyah Qibtiyah dengan penjelasn sebagai berikut:

Tabel 2. Top Figure

\begin{tabular}{|c|c|c|}
\hline No & Nama & Keteladanan \\
\hline 1. & Khadijah & Sang penyayang dan suport terbesar Nabi \\
\hline 2. & Saudah & $\begin{array}{lll}\text { a. } & \text { memiliki otak cemerlang } & \\
\text { b. } & \text { teguh dalam } \\
& \text { pendirian(dikucilkan } & \text { oleh } \\
& \text { keluarganya) } & \\
\text { c. ikhlas dalam berbagi suami } \\
\text { d. mengharap ridho ketika menjadi } \\
& \text { istri }\end{array}$ \\
\hline 3. & Aisyah & $\begin{array}{l}\text { Tabah (dengan terjadi fitnah), cerdas dan berani } \\
\text { (mengikuti dan memimpin peperangan) }\end{array}$ \\
\hline 4. & $\begin{array}{l}\text { Hafsah binti Umar } \\
\text { bin Khattab }\end{array}$ & $\begin{array}{l}\text { a. salah satu penulis wahyu, karena pandai } \\
\text { baca tulis } \\
\text { b. penyimpan mushaf Al Quran dan penghafalnya } \\
\text { c. istri yang ahli hadits }\end{array}$ \\
\hline 5. & Ummu Salamah & $\begin{array}{l}\text { a. penenang kegelisahan } \\
\text { b. penasehat ulung }\end{array}$ \\
\hline 6. & Zainab binti Jahsyi & $\begin{array}{l}\text { a. ahli sedekah } \\
\text { b. senang berpuasa dan pandai memasak } \\
\text { c. senang bersilaturahmi }\end{array}$ \\
\hline 7. & Juwairiyah & $\begin{array}{lll}\text { pemberi } & \text { kebabasn } & \text { kaumnya, } \\
\text { Musthaliq } & & \end{array}$ \\
\hline 8. & Shafiyah & $\begin{array}{l}\text { jembatan dakwah bagi kaum } \\
\text { Yahudi }\end{array}$ \\
\hline 9. & Ummu Habibah & $\begin{array}{lllll}\text { pemersatu } & \text { antara Nabi } & \text { Muhammad } & \text { dan } & \text { Abu } \\
\text { Saufyan } & & & & \\
\end{array}$ \\
\hline 10. & $\begin{array}{l}\text { Maimunah binti } \mathrm{Al} \\
\text { harits }\end{array}$ & Penganjur Silaturahmi \\
\hline
\end{tabular}

Berdasarkan profil ummatul mukminin, maka cakupan dan implikasi adabul marah sangat luas tidak hanya berimplikasi pada wilayah domestik, namun juga non domestik. Statement yang menyatakan bahwa " di belakang suami dan anak hebat pastilah anak istri dan ibu yang hebat " merupakan implikasi logis yang perlu ditindaklanjuti guna diaplikasikan secara kongkrit. Hal ini dikuatkan dengan hadits Rasulullah, sebagai berikut:

... كادي تبرت نيدلا تاذب رفظاف اهنيدل و اهلمجل و ,اهبسحل و اهلامل : عبرل ةأرملا حكنت...

Hadits tersebut menegaskan bahwa wanita terbaik adalah wanita yang paling baik agamanya. Artinya, wanita dituntut untuk terus melakukan kajian-kajian terhadap Al Qur an secara istiqamah yang dapat memberikabn penjelasan kongkrit dan lurus terkait apa yang dibutuhkan. 


\section{PENUTUP}

Wanita sebagai makhluk istimewa tidak harus memposisikan diri sebagai sosok yang harus dipahami tapi juga sosok yang mampu memahami. Surat An Nisa dapat dijadikan pijakn untuk melakukan kedua hal tersebut. Relasi yang seimbang ini hanya akan bisa dilakukan selama pengkajian terhadap ajaran abadi selalu dilakukan secara istiqamah. Perilaku inilah yang akan menghasilkan sawah dan produsen generasi emas yang sangat dibutuhkan negara dan bangsa.

\section{DAFTAR PUSTAKA}

Al Maraghi (1986).Terjemah Tafsir al Maraghi Jilid 4. (Bahrun Abubakar, Trans.). Semarang: CV Toha Putra.

Abul, Sayid hasan. (2000). Nahjul Balaghah : Selection From Sermons, Letters and Sayings of Amirul Mukminin Ali bin Abi Thalib, pen. Muhammad Hasyim assagaf, Puncak Kefasihan, Pilihan Khotmah, surat, dan ucapan Amirul Mukminin Ali Bin Thalib. Jakarta: Lentera Basritama.

Antonio, Syafii, 2010, Management Super leaderhip Nabi Muhammad, Tazkia, Jakarta.

Hade, Syarif masyah (Ed).(2010). Ensiklopedi Kemukjizat Al Qur an dan hadits jilid 2 , Jakarta: Sapta santosa.

Muhammad, Abubakar. (1994). Pembinaan Manusia Dalam Islam. Surabaya: Al ikhlas.

Shihab, Quraisy. (2001) Membumikan al Quran. Jakarta: Al Husna. 